\title{
An Exploratory Study into Social Cost Considerations in Ghanaian Construction Industry
}

\author{
James Cofie Danku*, Theophilus Adjei-Kumi, Bernard Kofi Baiden, Kofi Agyekum \\ Department of Construction Technology and Management, Kwame Nkrumah University of Science and Technology, Kumasi, \\ Ghana, West Africa \\ Email: ${ }^{j}$ mcdanku@yahoo.com
}

How to cite this paper: Danku, J.C., Adjei-Kumi, T., Baiden, B.K. and Agyekum, K. (2020) An Exploratory Study into Social Cost Considerations in Ghanaian Construction Industry. Journal of Building Construction and Planning Research, 8, 14-29.

https://doi.org/10.4236/jbcprt.2020.81002

Received: November 30, 2019

Accepted: January 7, 2020

Published: January 10, 2020

Copyright $\odot 2020$ by author(s) and Scientific Research Publishing Inc. This work is licensed under the Creative Commons Attribution International License (CC BY 4.0).

http://creativecommons.org/licenses/by/4.0/

\begin{abstract}
Construction causative nuisances, inconveniences, interferences and disruptions to the routine economic and social life patterns of adjacent or neighboring communities are referred to as social cost. This study explores the understanding and level of consideration of social cost by construction professionals in Ghana. Relevant literature sources are reviewed to define, rationalize and classify social cost. The study used the survey approach with a set of questionnaires addressed to construction contractors and professionals to gather the data. It was realized that not much consideration is given to social cost at the tender stage of the construction process. The five factors hindering social cost inclusion in tendering are "difficulty in allocating social costs", "governmental interferences", "lack of historical data", "lack of appreciation of social costs" and "low stakeholder agitation". The paper advocated for integration of social cost into the tendering process. The study will serve as a foundation to design a social cost assessment system at the pre-contract stage.
\end{abstract}

\section{Keywords}

Social Cost, Construction Industry, Construction Professionals, Community, Ghana

\section{Introduction}

The construction industry is pivotal for the socio-economic development of a country. Its diverse products are located in urban as well as rural areas. They include factories and houses; schools, offices and hospitals; social and sports 
facilities; roads, ports and railway, water, sewage and telecommunication infrastructure. Thus, it can be acknowledged that construction is a large, complex, dynamic, and intricate industry [1] [2]. All forms of construction activities generate costs. Some costs can be attributable to and borne by direct parties engaged in the contract, i.e. project participants-owners, other professionals (architects, quantity surveyors, engineers) and contractors. These contractual costs are identifiable, prudently classifiable and quantifiable by traditional estimating techniques for incorporation into the tender [3] [4]. The other groups of construction costs are considered peripheral to the project. [5] opined that they are not allowed for at the planning, design or tendering stages of construction because these formal contractual parties do not bear the costs. Costs relating to pollution (air, noise, water, vibration and dust), prolonged road closures, damages to utility services and physical environment, traffic detours and loss of economic activities are usually not incorporated into tenders because they cannot be calculated using standard estimating techniques. [5] further iterated that construction activities, particularly in built-up or urban areas, generate adverse environmental impacts in the form of pollution, traffic interruptions and interference in daily economic and social life patterns of adjacent residents. These construction contributory negative impacts on contiguous communities are referred to as social costs. Social costs vary greatly in quantum, duration and negative effects on urban residents. This is not surprising as construction is a conglomeration of diverse activities undertaken in, on and above ground. Social costs could be marginal or even negligible in certain instances but are substantial in most urban communities. In a report on social cost considerations for municipal infrastructure management in the United Kingdom, [3] discovered that social costs increased as much as four hundred per cent $(400 \%)$ of construction costs for sewer projects. How can the direct parties to the project minimize the social costs to other stakeholders? Addressing social cost commences with awareness and recognition of its existence. What is the level of knowledge and appreciation of social costs by construction practitioners? This paper primarily focuses on the assessment of the current level of understanding and extent of considerations of social costs by contractors and allied professionals in the construction industry in Ghana. This aim was achieved through a review of pertinent literature and analysis of responses based on a survey questionnaire to contractors and construction professionals. The outcome of the survey should provide a basis for subsequent social cost quantification and allocation strategies at the pre-contract stage. The paper is structured into six key sections that include the introduction, review of relevant literature, methodology, results, discussion, and the conclusion.

\section{Literature Review}

This section reviews literature on the concept of social cost, social cost in construction, social cost rationalization and classification, and social cost 
mitigation and quantification.

\subsection{What Is Social Cost?}

The heterodox economic theory definition of social costs was used in this paper instead of the neoclassical economic theory. The latter defined social costs as the resultant sum of private costs incurred by direct individuals specifically involved in a transaction and external costs imposed on consumers (not directly involved) due to exposure to the transaction. Heterodox economic theorist, Karl William Kapp, disclosed that social costs are a largely non-market phenomenon which can be tangible and intangible damages and losses borne by third persons or the general public as a result of private economic activities [6] [7]. Citing Kapp (1950 \& 1983), [6] defined social costs as "all direct and indirect losses sustained by third persons or the general public as a result of unrestrained economic activities". The damages and losses are occasioned by economic activities driven by an obsession for profit by direct parties but shifted to and borne by other parties and communities. Social losses could manifest in adverse health effects on people, deterioration of property values and damage to property as well as diminution of natural wealth. [7] is of the view that social costs are unpaid costs by those who produce them. This position has been collaborated by [8] when they associated social costs to costs incurred by only third parties who are not contractually engaged in a project. Social costs spiraled from mere economic concept to find application in many industries, including construction. It is noteworthy that social cost is not synonymous or analogous to corporate social responsibility (or shared value). The latter is a voluntary and self-regulating commitment by business to social accountability to society towards the improvement of quality of life [9]. The former though is the cost consequence of a business's negative impact on society. Further, a social cost is not the same as social value which relates to the benefit a community derives from an organization operating within the locality [10].

\subsection{Social Costs in Construction}

One system of categorizing total construction project costs is into direct and indirect. Direct costs are related to owning the property. They include conception and development costs such as construction inputs (materials, plant and equipment as well as labor), overheads, taxes and insurances. Indirect costs can result from extraneous actions and peculiar factors of the project such as unplanned damage to adjoining property, administrative and office costs. Thus, indirect costs are the costs to parties not directly involved in the contract but incurred by a construction entity and public. Indirect costs to a construction entity are costs which are not related to a particular project and include administrative and personnel expenses, office and services charges. Social costs are a form of indirect costs borne by society (or public) but not considered or included in the construction tender [3]. Referring to trenchless construction 
technology, [11] and [12] stated that social costs are the monetary equivalence of business or loss of income, normal life pattern or loss of enjoyment and traffic disruptions, and adverse environmental impact to residents and commercial entities living near to the construction site due to construction activities. In other words, social costs are components of construction costs not apparent to, taken care of, or included in the tender price but shifted to and paid by communities living adjacent to the construction area. [4] and [13] took the view that social costs should be considered as external costs of a construction project or burdens to other parties who are not directly involved in the contract. They contended that society and the surroundings are negatively impacted by the project without any commensurate compensation. [14] and [15] defined social costs consequent to implementation of construction projects as construction causative adverse impacts that impinge on third parties or adjoining communities without due compensation. On his part, [5] believed that social cost is the cost of alterations in the routine lifestyles of residents as a consequence of construction activities.

The central motif of all the varied definitions of social costs of construction is that residents, their economic activities, health and social wellbeing are impacted negatively by construction activities which are undertaken within their communities. A social cost is a cost associated with maintaining the pre-construction routine of residents or at least assuaging construction causative nuisances, inconveniences and disruptions to lifestyle patterns on the society residing around the construction zones. Social costs are also incurred on third parties because of exposure to air and water pollution, noise, vibration and traffic disruptions. Social costs are not factored into traditional cost estimating systems consequently, they are not assimilated by the contractors or direct owners. Contractors, therefore, focus on cost-saving at the expense of prudent and environmentally sound construction machinery and alternative technologies [3] [5] [11] [12] [16].

\subsection{Social Cost Rationalization and Classification}

One way of classifying costs associated with the pre-contract and construction phases of building and civil engineering structures in urban centers is to relate the costs to the two main interest groups or stakeholders. The direct interest group includes the owners, designers, contractors, suppliers and immediate beneficiaries or users. The second category that has an indirect relation to the project are the external stakeholders or adjoining communities can be adversely impacted by construction activities. Costs to the former group are traditionally estimated and accounted for in the tender. As mentioned earlier, social costs to neighboring or adjoining communities are widely left out of the tender price [8] [11] [17]. This means that the contractor is not directly bound by the terms of the contract to minimize construction causative sociological, economic and ecological adverse impacts on surrounding society [17]. As a consequence, 
contractors are not incentivized for reducing these nuisances or punished for their breach. Surrounding communities bear the brunt of construction activities. The contractor should be encouraged or even compelled to adopt alternative working systems and technologies of construction with negligible pollution (air, dust, vibration or water), least traffic interruptions and minimum business costs to neighboring communities. On the other hand, communities adjacent to construction sites should be appeased or compensated for the negative effects of construction activities on their economic and social lives. The ease of communication as a result of the growing usage of social networking tools allows for quick dissemination of information and mobilization of external stakeholders against nuisances in urban areas. Acknowledgement and providing for social costs will not only ensure a just and cordial relationship between a project team and communities but prevent opposition, conflict, antagonism, delay or suspension of the project.

Several literatures reviewed categorized social costs into four main elements: traffic, economics activities, pollution and ecological/social/health (for example, [3] [4] [11] [12] [13] [14] [16] [17]). Traffic-related social costs involve disruptions to traffic due to delays and diversions. In fact, [13] intimated that traffic delay costs due to the increased time spent travelling can account for more than $50 \%$ of the total social cost of the project. Local businesses will be affected directly due to property damage, loss of income/turnover, production disturbances as well as a loss of tax revenue to the government. Noise, dirt, air, vibration and water pollutions can lead to increased costs to residents. Construction-related physical and mental health will require treatment at a cost. Other costs in this direction include restoration and compensation.

\subsection{Social Cost Mitigation and Quantification}

Costs incurred must be settled by individuals, parties, institutions or government. A party whose action (or inaction) generated the cost would bear the cost directly or a third party would serve as an insurer or a guarantor. Unfortunately, a social cost is incurred by the public although project participants, who are the direct stakeholders, contributed to it. One way of taking care of social cost is estimation and incorporation into the contract at the tendering process. However, [11] observed that "traditional contractual and bid evaluation practices do not account for economic losses resulting from construction-related activities that are borne by parties not engaged in the contractual arrangement". A similar position was taken by other researchers, including [3] [5] and [12]. According to [16], this is so because of the difficulty in measuring social costs. In instances where estimates are made for economic costs of traffic congestion emanating from construction works, for example, [18] observed that they vary greatly from the actual costs of the delays. The public bears the social costs in traditional contractual arrangements. This could be very significant in urban densely populated areas. To mitigate social costs, relevant construction codes of practice should be strictly 
enforced to serve as a deterrent to contractors seeking to circumvent any protocol. Contractors should opt for alternative technology with substantially less environmental impact. Construction operations should be effectively planned to reduce activity durations coupled with appropriate scheduling of work for off-peak periods to minimize the impact on communities [3] [5].

With regards to social cost quantification, researches have proposed some techniques for incorporation into the tender evaluation process. Most of the techniques can be found in underground infrastructure systems and roads. [19] identified four methods as Bidding on cost/time $(\mathrm{A}+\mathrm{B})$, Bidding on cost/time combined with incentive/disincentive, Incentive/disincentive (I/O) and Lane rental. [16] also recognized five methods that take social costs into account during construction bid evaluation process. They include the A $+\mathrm{B}$, Lane rental and Multi-parameter methods. The rests are Cost-effectiveness analysis and Multi-rating evaluation. These methods consider the value of time, in that time is treated as money which can be spent, saved, lost or wasted. For example, in the $\mathrm{A}+\mathrm{B}$ method, the estimated construction cost for the project is denoted by A while $B$ is an estimate of project duration and social costs. Lane rental is designed as a way to provide financial incentives to contractors in order to shorten construction time. Thus, the contractor has assessed a rental fee based on delay costs for the period when traffic is obstructed. [11] proposed seven valuation techniques employed to evaluate social cost indicators as a resource cost. They include four categories under direct costs as loss of productivity, human capital, replacement cost and lane rental costs. The indirect costs are Hedonic pricing, user delay costs and Contingent valuation technique. Details of these methods are not discussed in this paper. [4] also developed construction social costs (COSCO) model for quantifying traffic, environmental and business negative impacts of construction activities. [3] categorized social costs into three. Direct costs are attributable to the project and include property damages, municipal revenue losses, redundant and temporary systems. Direct costs can be incorporated into the tender. Traffic disruption costs, business losses, noise disturbance costs, dirt and dust costs and service life reduction fall into the second group as the indirect costs to the public. The last social costs category is considered as intangible and comprises health and safety, and environmental costs. Calculation of these social costs is based on historical data, compensation for loss and damages, derived formulae and percentage adjustments.

\section{Research Method}

This is an exploratory study which was aimed at testing the familiarity and understanding of Ghanaian construction practitioners on the concept of social costs. For this to be achieved, a set of literature was sourced to elucidate on social costs in general and specific application in the construction industry. The exploratory and descriptive survey strategy [20] was employed which facilitated the collection of quantitative data by the use of a questionnaire, descriptive 
analysis and inferential statistics. The sets of questionnaires were administered to building and road contractors as well as other professionals such as project managers, quantity surveyors, civil/structural engineers and architects in the two largest cities in Ghana; Accra and Kumasi. Purposive sampling approach was adopted in selecting relevant respondents [21]. Questionnaires were distributed by on-line survey using "Google forms" survey administration application tool and hand delivery. The questions were of the closed-ended type to enable respondents to quickly and unambiguously assess their level of familiarity and extent of use of social costs in the Ghanaian construction industry [20] [22]. A total of two hundred and fifteen (215) questionnaires were administered to construction professionals. Although one hundred and fifty-one (151) were returned, seventeen were considered as non-responsive therefore rejected. Subsequently, one-hundred and thirty-four (134), representing a response rate of sixty-two per cent (62\%), were used in the analysis. Table 1 shows the distribution of the background of respondents. Forty-two respondents were working with general building firms, 18 into civil engineering (road) works and

Table 1. Profile of respondents.

\begin{tabular}{|c|c|c|}
\hline Characteristics & Frequency $(\mathrm{N}=134)$ & Percentage \\
\hline \multicolumn{3}{|l|}{ Type of Construction work } \\
\hline General Building Works & 42 & 31.3 \\
\hline Civil Engineering Works & 18 & 13.4 \\
\hline Building/Civil Engineering works & 74 & 55.2 \\
\hline \multicolumn{3}{|l|}{ Profession } \\
\hline Project Manager & 22 & 16.4 \\
\hline Quantity Surveyor & 68 & 50.7 \\
\hline Engineer & 21 & 15.7 \\
\hline Architect & 17 & 12.7 \\
\hline Others & 6 & 4.5 \\
\hline \multicolumn{3}{|l|}{ Company } \\
\hline $\mathrm{D} 1 \mathrm{~K} 1$ & 19 & 14.2 \\
\hline $\mathrm{D} 2 \mathrm{~K} 2$ & 24 & 17.9 \\
\hline D3K3 & 9 & 6.7 \\
\hline Consultancy Services & 55 & 41.0 \\
\hline A1B1 & 12 & 8.9 \\
\hline A2B2 & 9 & 6.7 \\
\hline A3B3 & 3 & 2.2 \\
\hline Others & 3 & 2.2 \\
\hline \multicolumn{3}{|l|}{ Working Experience } \\
\hline $1-5$ years & 11 & 10.9 \\
\hline $6-10$ years & 28 & 27.5 \\
\hline $11-15$ years & 32 & 31.4 \\
\hline $16-20$ years & 16 & 15.7 \\
\hline Over 20 years & 15 & 14.7 \\
\hline
\end{tabular}


over fifty per cent were into both building and civil construction works. The quantity surveyors represented a majority of respondents (over 50\%). Forty-three tiers one and two general building contractors (D1K1 and D2K2) participated in the survey. Out of the 134 companies, about sixteen per cent represented classes one and two road construction firms (A1B1 and A2B2) while fifty-five came from the various construction consultancy services. In Ghana, class $D$ contractors are engaged in general building works while class $A$ contractors undertake Roads, Airports and related structures. Financial capacity, equipment holding and human resources are used to categorize contractors into four. Financial class 1 contractors have no limit on the amount of contract they can tender for. While class 2 contractors cannot handle works in excess of US\$ 500,000; the limit for class 3 contractors is US\$200,000. The demographic information on respondents also indicated that 123 had worked for over six years in the industry. In fact, thirty-one per cent of respondents had over 15 years of working experience in the construction industry. It can, therefore, be concluded that the respondents possess adequate experience to provide data for the study.

\section{Results}

The construction industry plays a critical role in the socio-economic development of Ghana. It contributes substantially to the gross domestic product (GDP) [2] [23]. New urban construction infrastructure, including offices, houses, schools, hospitals, water supply, sewerage and roads are emerging. Existing ones too are being maintained, repaired, rehabilitated or renewed. These projects though improve living standards, generate adverse impacts at their construction phases on people within the surrounding environment. Costs of economic losses, health and social inconveniences which are described as social costs, could be quite considerate in densely populated municipal and metropolitan centers. To address these social costs, construction professionals must understand the concept and incorporate it into the design, planning and tender evaluation phases of construction projects. Social cost assessment can be effective when considered at the early stages of the project.

\subsection{Social Cost Inclusion in Tenders}

To assess the construction professionals' familiarity and application of this category of costs, respondents were asked whether social costs were included in tenders for public and commercial buildings and roads in urban settlements. The views of the quantity surveyors were treated distinctly from other professionals because they are the direct cost consultants. Although not dealing directly with cost estimating or preparation of the bill of quantities, the varied activities or omission of the project managers, civil/structural engineers and architects will have a cost consequence on neighboring communities. It is therefore incumbent to seek their perspectives on social costs. The responses of 
the quantity surveyors separately and project managers, civil/structural engineers and architects collectively are presented in Figure 1. Forty-seven $(69.12 \%)$ quantity surveyors out of 68 did not factor social costs into the tendering. Regarding other professionals (project managers, civil/structural engineers and architects), only forty-five per cent of the total of 66 considered social cost at the pre-contract stage. Based on Figure 1, only $38 \%$ of the total respondents of 134 professionals, declared that they consider social cost at tendering.
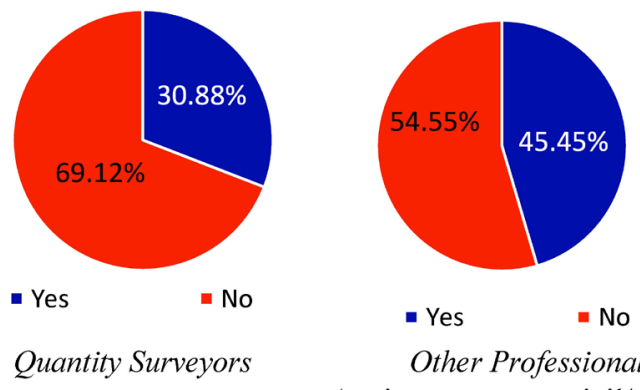

Other Professionals

(project managers, civil/structural engineers and architects)

Figure 1. Social cost inclusion in tenders.

\subsection{System of Social Cost Estimation}

It is not enough just claiming to be accounting for social cost in construction tenders without providing details of the method. The 51 respondents who indicated the inclusion of this cost in tenders were further tasked to specify the systems and estimating techniques employed (Figure 2 and Figure 3). Given the choice of a respondent selecting any appropriate options out of the four systems presented, 19 quantity surveyors favored a new system, 16 and 14 considered an overhaul and improvement of the current system respectively and 8 preferred the status quo. From Figure 2, the other professionals' responses gave "an improvement upon the current system" the highest number of 26 and "a new system of estimating social cost" the least of seventeen. The "overhaul and recommendation of the existing systems" had 23 and 22 respectively. It is difficult to deduce from the foregoing as to whether the 51 professionals actually considered social costs in their tenders. This position is reinforced by the low responses of quantity surveyors "recommending the current social cost system" which could be indicative of the absence of a current system.

\subsection{Social Cost Estimation Methods}

The five methods of estimating social costs identified in the literature ([11] [16] [19]) as bidding on cost/time, incentive/disincentive, bidding on cost/time combined with incentive/disincentive, lane rental and traditional were presented to those professionals who indicated that they consider social cost in tendering. As can be seen in Figure 3, there was low patronage of the methods. Focusing on quantity surveyors, as the core cost practitioners, it can be deduced that on 


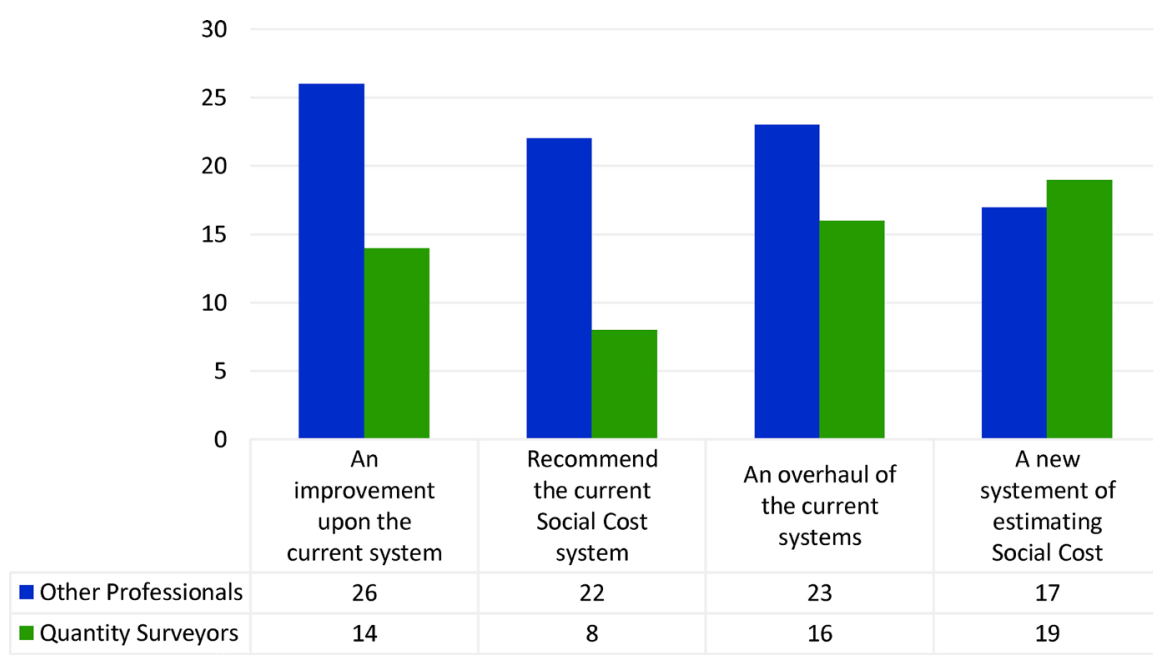

Figure 2. System of social cost estimation.

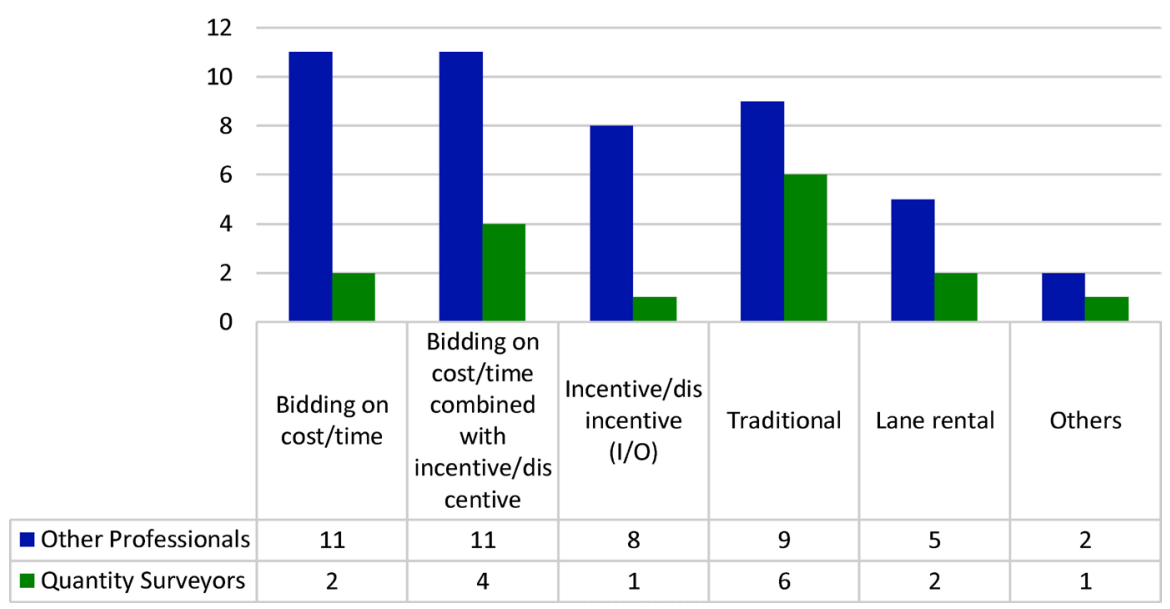

Figure 3. Social cost estimation methods.

average, three indicated the use of one of the methods. Only one was using an incentive/disincentive method and two also specified the use of bidding on cost/time and lane rental methods. The highest number of six chose the traditional method which can be argued here as rather vague or ambiguous. The opinions of the other professionals can only be regarded as a mere awareness of the methods instead of actual usage.

\subsection{Accounting for Social Costs in Buildings/Road Projects}

Majority of respondents did not consider or incorporate the social cost into their tenders for building/road projects. A total of eighty-two per cent of the 134 professionals did not incorporate social cost in tenders. Out this number, 47 were quantity surveyors and 36 represented other professionals. If social costs are not factored into the tender, how are they taken care of? According to [14], they could be incorporated into social impact assessment, cost-benefit analysis, economic appraisal, environmental impact assessment and social value assessment. As can be gathered from Figure 4, the quantity surveyors were of 


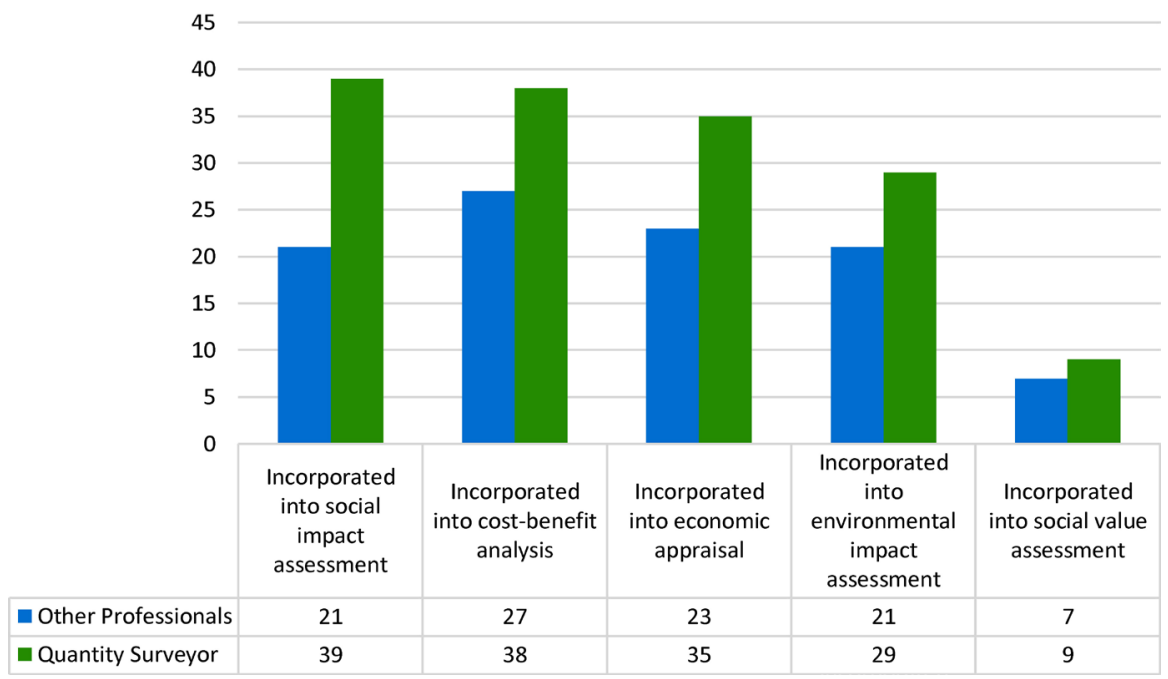

Figure 4. Accounting for social costs in building/road projects.

the view that they could be incorporated into either social impact assessment (39) or cost-benefit analysis (38). While thirty-five quantity surveyors advised that social cost should be considered under economic appraisal, twenty-nine preferred environmental impact assessment. As the five factors are not mutually exclusive, the responses portrayed a marginal difference in four, with only "incorporated into social value assessment" having a low response of 9. The other professionals too followed a similar outline. It can be inferred that social cost was not treated in any particular manner.

\subsection{Reasons for Omitting Social Costs in Tenders}

There was a need to investigate why the social cost was not considered at the tender stage. Could this be attribufigure to "difficulty in allocating social costs", "governmental interferences", "lack of historical data", "lack of appreciation of social costs" and/or "low stakeholder agitation" [4] [16]? With over fifty per cent of respondents in both categories (quantity surveyors and others) suggesting these factors, Figure 5 shows that all of the five factors contributed in a great measure to the absence of social costs in tenders. Forty quantity surveyors considered "lack of appreciation of social costs" as the main reason for omitting social costs from tenders and twenty-four out of the forty-seven attributed this to "low stakeholder agitation". On average, thirty-four quantity surveyors out of the forty-seven held the view that the five factors contributed to the absence of social costs in tenders. The proportion for the other professionals was twentyfour out of the thirty-six responses.

\subsection{Mitigation of Social Cost Impact on Communities and Businesses}

Communities and businesses living close to construction sites incur social costs.

[3] recommended four mitigation measures viz., "timing work for off-peak hours", "using alternative rehabilitation technology", "coordinating with other 
work in close proximity" and "reducing the duration of work". The forty-seven quantity surveyors and thirty-six project managers, civil/structural engineers and architects (other professionals) were requested to indicate their social cost mitigation measures. The result has been presented in Figure 6. It can be observed that all methods were highly appreciated. On average, thirty-nine out of the forty-seven (83\%) quantity surveyors recommended the use of the four methods for social cost mitigation. The proportion for the other professionals was sixty-nine per cent (or thirty-one out of forty-five).

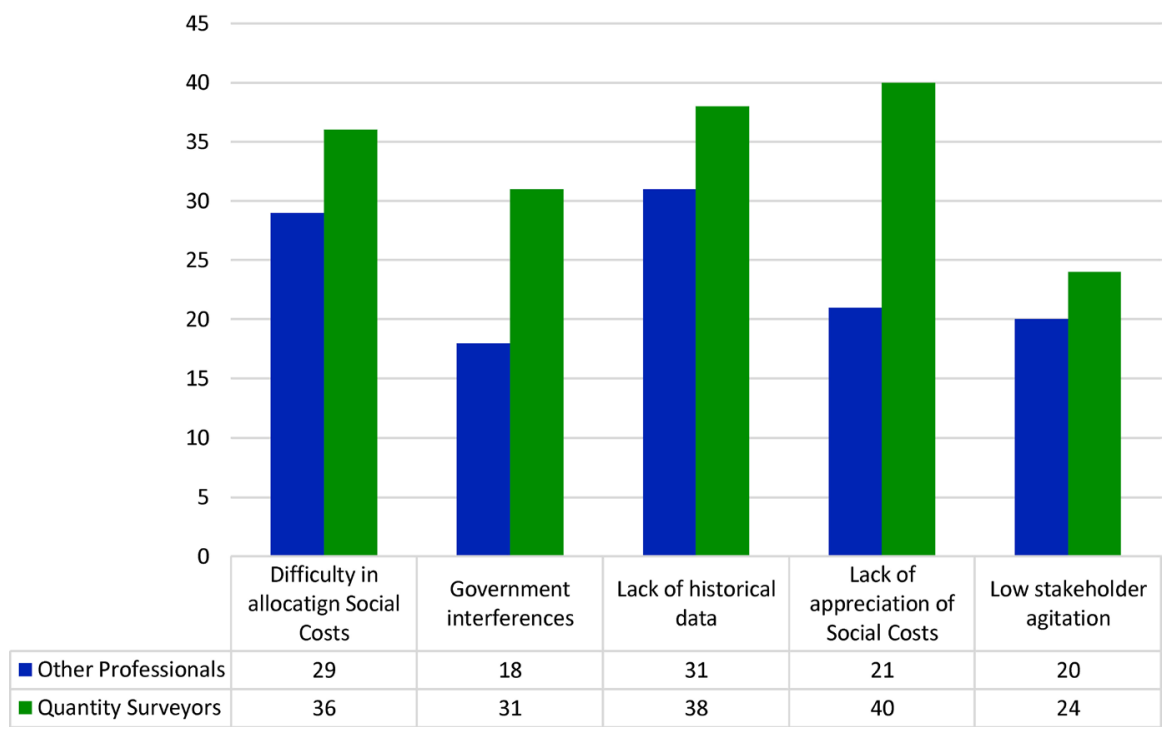

Figure 5. Reasons for omitting social costs in tenders.

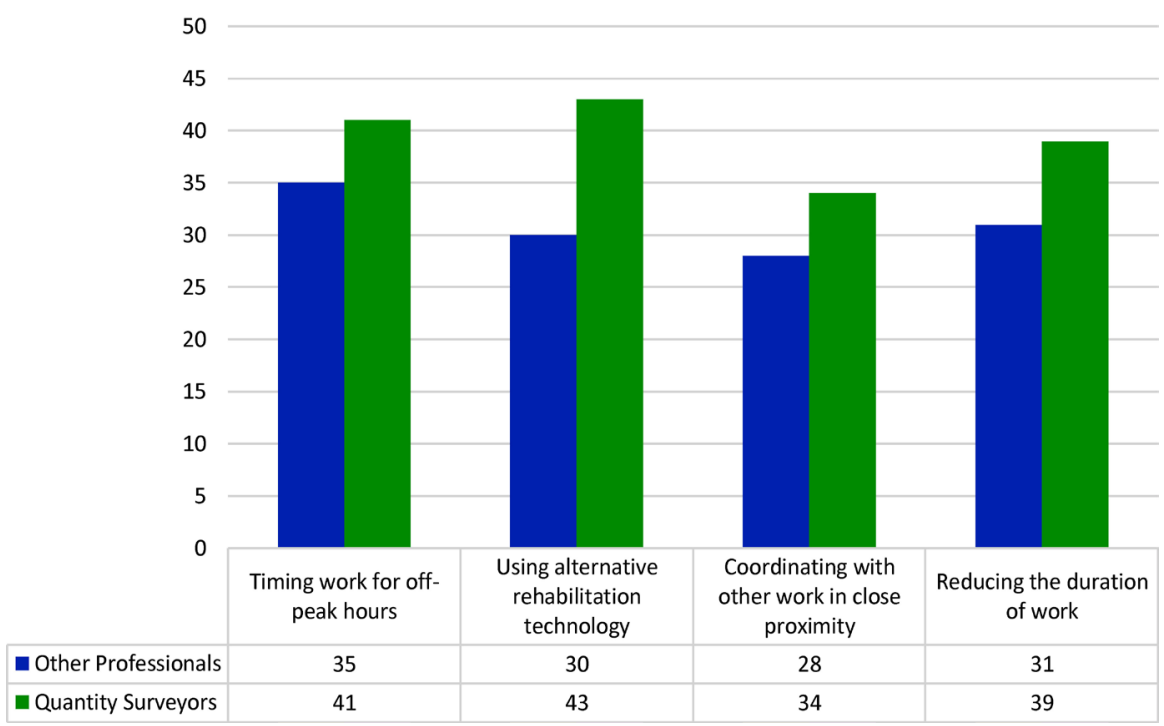

Figure 6. Mitigation of social cost impact on communities and businesses.

\section{Discussion}

Majority of construction professionals did not consider social costs in tenders.

Close to seventy per cent (70\%) of the sixty-eight quantity surveyors ignored 
social costs at the contract stage. The percentage for the other professional was fifty-five of the sixty-six respondents. High though this might appear, the reliability of the remaining thirty-eight per cent who indicated social costs inclusion in tenders could be questioned. This is based on their inability to clearly state the system and techniques employed to account for social costs. In fact, only a low average of about three quantity surveyors out of the twenty-one respondents could specify at least one method of allowing for social costs in tenders. For other professionals too, only an average of eight from the thirty who responded in the affirmative to the inclusion of social costs in tenders were able to assign at least a method. This, therefore, cast doubt on the reliability of their understanding and use of social costs. Thus, it can be concluded that social costs are not included in tenders in the Ghanaian construction industry.

None of the techniques listed in Figure 4 wholly caters for social costs. Social impact assessment is concerned with identifying and managing negative social impacts of construction activities and recognizing opportunities that will inure to the benefits of local communities. Cost-benefit analysis deliberates on direct costs and benefits to society of a proposed project with the view of efficient allocation of resources [24]. Closely related to this is the economic appraisal which also looks at a series of costs and benefits of a project. While environmental impact assessment concentrates on a process of evaluating likely beneficial and adverse environmental impacts of a project on socio-economic and lifestyle of adjacent communities. As mentioned earlier, social value is the benefit derived by a community from an organization operating in the locality [10]. The five factors considered as key hindrances to the inclusion of social factors in tendering are "difficulty in allocating social costs", "governmental interferences", "lack of historical data", "lack of appreciation of social costs" and "low stakeholder agitation". All of these were rated high by both gorupsquantity surveyors and other professionals. Eighty-five per cent of quantity surveyors indicated that "lack of appreciation of social costs" was the main reason for omitting social costs from tenders and over fifty per cent attributed this to "low stakeholder agitation" (Figure 5). Depending on the type and construction technique employed, and concentration of people and businesses, social costs can vary greatly in scope and quantum. There was a high return rate of the four mitigating factors of social costs namely "timing work for off-peak hours", "using alternative rehabilitation technology", "coordinating with other work in close proximity" and "reducing the duration of work". The average of eighty-five per cent posted by the quantity surveyors and other professionals can be interpreted in terms of the need for judicious execution of projects to minimize social costs. Some of these considerations, for example, "using alternative rehabilitation technology", have the propensity to increase contractor's cost in contrast to reduced social cost. This position thereby lends strong support to social costs inclusion in construction projects in urban areas where the effect can be appreciable. 


\section{Conclusion}

The study revealed that construction professionals do not incorporate social costs of contracts into tenders. Alternative systems such as social impact and value assessment, cost-benefit analysis, economic and environmental appraisal, suggested by the practitioners do not wholly address these costs. The number of factors accounting for this state of affairs varies from "difficulty in allocating social costs", "governmental interferences", "lack of historical data", "lack of appreciation of social costs" to "low stakeholder agitation". There is the need to assess the potential social cost impact on inhabitants not only as a measure for compensation or the determination of premium for insurance but as a check against contractor adopting techniques and use of machines and equipment with dire social cost consequences. Social cost would be greatly reduced if owners and contractors justify their choice of construction techniques, methods and practices based on current valuation standards which incorporate cost to the society at large. The effects of social cost can also be mitigated by timing work for off-peak hours, proper coordination of work and possible reduction of work duration. It is important also that, construction codes and regulations are strictly adhered to by owners and contractors. In developing countries like Ghana, effective rules should be enacted to address current construction challenges as well as tightening existing ones such as Environmental Protection Agency Act 490 (1994) to check the adverse impacts on communities and environment associated with construction projects in urban areas. Finally, the study underlines the need for the development of a system for estimating and incorporating social costs into tenders.

\section{Conflicts of Interest}

The authors declare no conflicts of interest regarding the publication of this paper.

\section{References}

[1] Behm, M. (2008) Construction Sector. Journal of Safety Research, 39, 175-178. https://doi.org/10.1016/j.jsr.2008.02.007

[2] Osei, V. (2013) The Construction Industry and its Linkages to the Ghanaian Economy-polices to Improve the Sector's Performance. International Journal of Development and Economic Sustainability, 1, 56-72.

[3] Rahman, S., Vanier, D.J. and Newton, L.A. (2005) MIIP Report: Social Cost Considerations for Municipal Infrastructure Management. NRC Publications Archive, Ottawa.

[4] Yu, W.D. and Lo, S.S. (2005) Time-Dependent Construction Social Costs Model. Construction Management and Economics, 23, 327-337. https://doi.org/10.1080/01446190500040281

[5] Celik, T. (2014) Developing a Building Construction Associated Social Cost Estimation System for Turkish Construction Industry. Ph.D. Thesis, The University of Salford, Salford. 
[6] Berger, S. (2008) K. William Kapp's Theory of Social Costs and Environmental Policy: Towards Political-Ecological Economics. Ecological Economics, 67, 244-252. https://www.sciencedirect.com https://doi.org/10.1016/j.ecolecon.2008.05.012

[7] Neves, V. (2018) The Theory of Social Costs of K. William Kapp: Some Notes on Sebastian Berger's The Social Costs of Neoliberalism. Forum for Social Economics. https://doi.org/10.1080/07360932.2018.1481127

[8] Allouche, E.N., Ariaratnam, S.T. and Abourizk, S.M. (2000) Multi-dimensional Utility Model for Selection of a Trenchless Construction Method. Construction Congress VI: Building Together for a Better Tomorrow in an Increasingly Complex World, American Society of Civil Engineers, Reston, VA, 543-553. https://doi.org/10.1061/40475(278)59

[9] McWilliams, A., Siegel, D.S. and Wright, P.M. (2006) Corporate Social Responsibility: Strategic Implications. Journal of Management Studies, 43, 1-18. https://doi.org/10.1111/j.1467-6486.2006.00580.x

[10] Daniel, E.I. and Pasquire, C. (2019) Creating Social Value within the Delivery of Construction Projects: The Role of Lean Approach. Engineering, Construction and Architectural Management, 26, 1105-1128. https://doi.org/10.1108/ECAM-06-2017-0096

[11] Gilchrist, A. and Allouche, E.N. (2005) Quantification of Social Costs Associated with Construction Projects: A State-of-the-Art Review. Tunnelling and Underground Space Technology, 20, 89-104. https://doi.org/10.1016/j.tust.2004.04.003

[12] Apeldoorn, S. (2013) Comparing the Costs-Trenchless versus Traditional Methods. MIESA, 38, 55-57.

[13] Matthews, J.C. and Allouche, E.N. (2010) A Social Cost Calculator for Utility Construction Projects. North American Society for Trenchless Technology, Chicago, IL.

[14] Celik, T., Kamali, S. and Arayici, Y. (2017) Social Cost in Construction Projects. Environmental Impact Assessment Review, 64, 77-86. https://doi.org/10.1016/j.eiar.2017.03.001

[15] Tanwani, R. (2012) Social Costs of Traditional Construction Methods. Gunda Corporation.

https://www.gundacorp.com/wp-content/uploads/2011/12/Social-Costs_TechnicalArticle_Formatted_FINAL.pdf

[16] Xueqing, W., Bingsheng, L., Allouche, E.N. and Liu, X.Y. (2008) A practical Bid Evaluation Method Considering Social Costs in Urban Infrastructure Projects. 2008 4th IEEE International Conference on Management of Innovation and Technology, Bangkok, 21-24 September 2008, 617-622. https://doi.org/10.1109/ICMIT.2008.4654436

[17] Celik, T. and Budayan, C. (2016) How the Residents Are Affected from Construction Operations Conducted in Residential Areas. Procedia Engineering, 161, 394-398. https://doi.org/10.1016/j.proeng.2016.08.580

[18] Goodwin, P. (2005) Utilities' Street Works and the Cost of Traffic Congestion. http://streetworks.org.uk/wp-content/uploads/2016/09/93.pdf

[19] Herbsman, Z.J., Chen, W.T. and Epstein, W.C. (1995) Time Is Money: Innovative Contracting Methods in Highway Construction. Journal of Construction Engineering and Management, 121, 273-281. https://doi.org/10.1061/(ASCE)0733-9364(1995)121:3(273)

[20] Saunders, M., Lewis, P. and Thornhill, A. (2009) Research Methods for Business 
Students. 5th Edition, Pearson Education Limited, Harlow.

[21] Neuman, L.W. (2006) Social Research Methods: Qualitative and Quantitative Approaches. Pearson Education, Boston, MA.

[22] Fellows, R. and Liu, A. (2008) Research Methods for Construction. 3rd Edition, Blackwell Publishing Ltd., Hoboken, NJ.

[23] Owoo, N.S. and Lambon-Quayefio, M.P. (2018) The Role of the Construction Sector in Ghana. WIDER Working Paper, No. 2018/119. The United Nations University World Institute for Development Economics Research (UNUWIDER), Helsinki.

[24] Jones, H., Moura, F. and Domingos, T. (2013) Transport Infrastructure Project Evaluation Using Cost-Benefit Analysis. Procedia-Social and Behavioral Sciences, 111, 400-409. https://doi.org/10.1016/j.sbspro.2014.01.073 